\title{
Stoneflies (Plecoptera) of the Javorníky Mts (Czech Republic)
}

Jiří Kroča

Stoneflies (Plecoptera) of the Javorníky Mts (Czech Republic). - Acta Mus. Siles. Sci. Natur. 65: 105116, 2016.

\begin{abstract}
The investigation of three streams in the Moravian part of the Javorníky Mts in 2003 and 2006-2009 brings the first records of Plecoptera in these mountains. A total of 28 species and were found (30\% of the recent fauna of the Czech Republic), among which species of the upper parts of streams predominate. This result corresponds to the nature of the habitat on which researches have been carried out. One endangered species (Leuctra cf. major), two vulnerable species (Dinocras cephalotes, Perla marginata) and one near threatened species (Leuctra quadrimaculata) were recorded. Comparing the recorded species to those of the neighbouring mountains, it can be assumed that the fauna of stoneflies of the Javorníky Mts may contain more than 40 species and can form a continuous transition between the Moravskoslezské Beskydy Mts and the Bílé Karpaty Mts (including the Vizovická vrchovina Highlands).
\end{abstract}

Key words: Plecoptera, faunistics, Javorníky Mts, Carpathians, Moravia, Czech Republic

\section{Introduction}

Stoneflies (Plecoptera) are an important component of the fauna of the upper and middle parts of streams. Altogether 90 species of which 31 are listed in the Red List (historically 95 species of which five are extinct; Bojková \& Soldán 2013) are recently known from the Czech Republic.

No survey dealing with the diversity of stoneflies of the Javorníky Mts has been published to date. Altogether 10 species of stoneflies were obtained in the hydrobiological survey of Razula NNR (Kroča 2003). Further investigation was carried out at two sites in the basin of the Kychová brook in 2006-2009. Except for a remarkable record of Leuctra quadrimaculata Kis, 1963 (Kroča 2011), the data remained unpublished.

The aim of this study is the summarisation of all available records of stoneflies known from the Moravian part of the Javorníky Mts New data on stoneflies of the Kychová basin, based mostly on findings of adults, are presented. Furthermore, the material of stoneflies (both larvae and adults) from the Razula NNR was revised.

\section{Material and methods}

The geomorphological unit of the Javorníky Mts is located in the eastern Moravia, it is a part of the Outer Western Carpathians (subprovince), subsystem of the Moravian-Slovak Carpathians (Magurian flysch). From the nature conservation point of view, Kychová stream and its tributary are located in the Beskydy PLA and Malá Hanzlůvka stream flows through the Razula National Nature Reserve (Tab 1 and Fig 1). The investigated sites are located in the upper sections of the streams representing hypocrenal and epirhitral habitats.

The Inventory survey of Razula NNR was carried in 2003. Hydrobiological sampling was performed semiquantitatively (method Perla; Kokeš \& Němejcová 2006) using a hand net $(25 \mathrm{~cm}$ in diameter, $0.5 \mathrm{~mm}$ mesh size) and samples were fixed in $4 \%$ formaldehyde. Adults of stoneflies were collected by sweeping and fixed in $70 \%$ alcohol. The field work was carried out on the following dates: 19 April; 24 May; 7 June (only sweeping); 27 July and 18 September.

The investigation of Makyta and Malá Tisová was carried in 2006-2009 using the same sampling methods as in the Razula NNR. Sampling was conducted on the following dates: 23 May 2006; 16 August 2006; 30 October 2006; 12 February 2007; 16 April 2007; 6 August 2007; 8 October 2007 and 10 March 2008. 
Adults of stoneflies were collected by Malaise traps installed above the streams from 13 March to 27 November 2007 and emptied every four to five weeks. Sweeping was carried out as a complementary method. The samples were fixed in 70\% alcohol. All material was collected and determined by J. Kroča and it is deposited in the T. G. Masaryk Water Research Institute, p.r.i. in Brno (coll. J. Kroča, Plecoptera).

The nomenclature of stoneflies and conservation status of species in this paper follow Bojková \& Soldán (2013). The distribution and ecological preferences are based on Graf et al. (2009). The sites are supplemented by grid references based on Zelený (1972) and Pruner \& Míka (1996).

The following abbreviations are used: NNR - National Nature Reserve, PLA - Protected Landscape Area; MT - Malaise trap, HS - hydrobiological samples, SW - sweeping; EN - endangered species, VU - vulnerable species, NT - Near threatened species; L - larva, $\widehat{O}-$ male, $q-$ female.

Tab 1: Characteristics of studied localities

\begin{tabular}{lccll}
\hline Locality & Quadrat & $\begin{array}{l}\text { Altitude } \\
{[\mathrm{m} \text { a. s. 1.] }}\end{array}$ & Stream & Coordinates \\
\hline $\begin{array}{l}\text { Razula } \\
\text { NNR }\end{array}$ & 6676 & $665-770$ & $\begin{array}{l}\text { Malá } \\
\text { Hanzlůvka }\end{array}$ & $\begin{array}{l}49^{\circ} 21^{\prime} 41.779^{\prime \prime} \mathrm{N} \\
18^{\circ} 22^{\prime} 50.033^{\prime \prime} \mathrm{E}\end{array}$ \\
\hline Makyta & 6775 & 665 & Kychová & $\begin{array}{l}49^{\circ} 16^{\prime} 33.266^{\prime \prime} \mathrm{N} \\
18^{\circ} 10^{\prime} 44.574^{\prime \prime} \mathrm{E}\end{array}$ \\
\hline $\begin{array}{l}\text { Malá } \\
\text { Tisová }\end{array}$ & 6774 & 547 & $\begin{array}{l}\text { Kychová } \\
\text { left tributary }\end{array}$ & $\begin{array}{l}49^{\circ} 16^{\prime} 29.188^{\prime \prime} \mathrm{N} \\
18^{\circ} 8^{\prime} 38.537^{\prime \prime} \mathrm{E}\end{array}$ \\
\hline
\end{tabular}

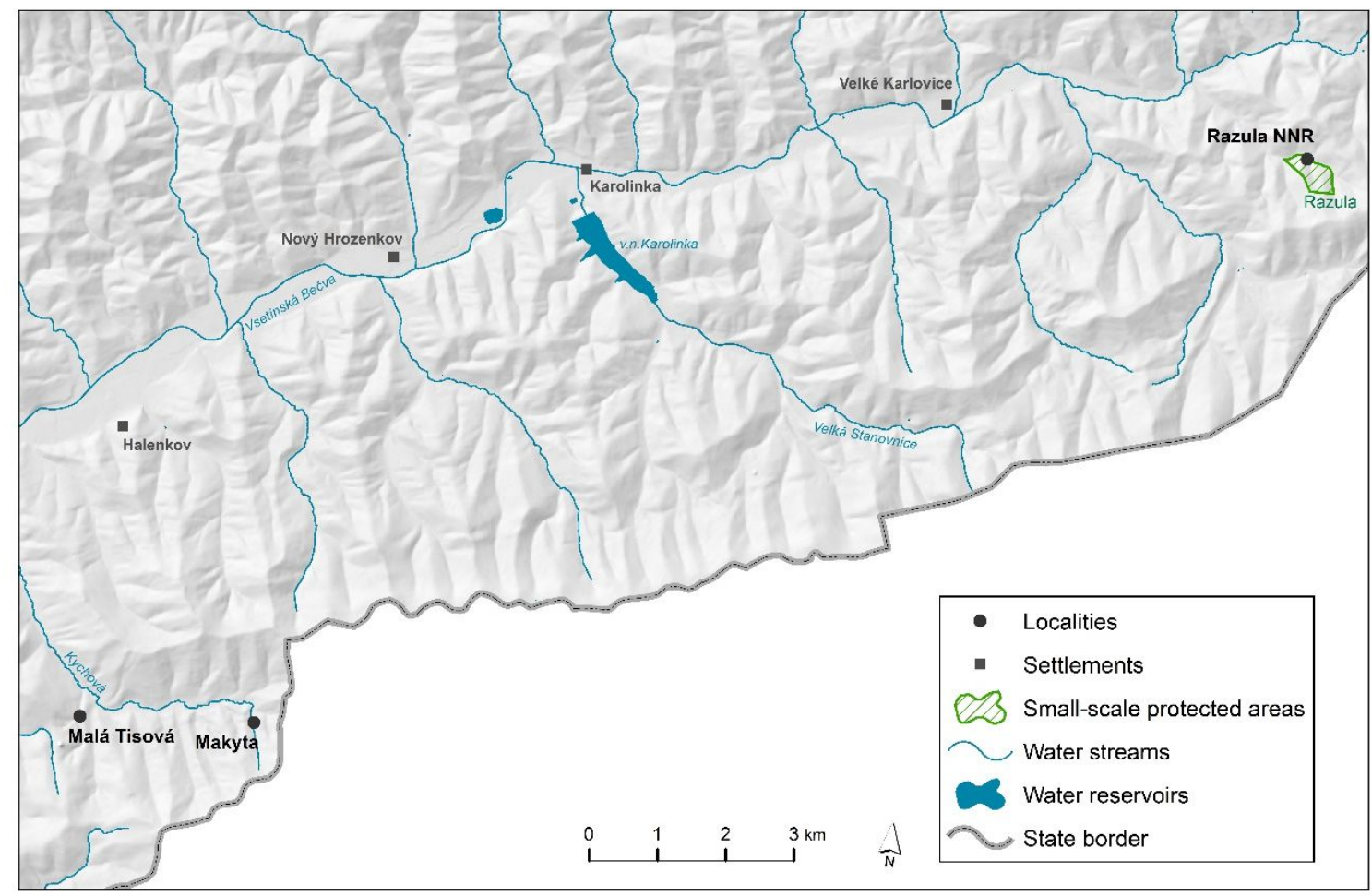

Fig 1: Map of localities. 


\section{Results}

\section{Dinocras cephalotes (Curtis, 1827) (VU)}

Razula NNR, 24.v.2003, 3 L; 18.ix.2003, 2 L, both HS.

A European species common in fast-flowing mountain and submountain streams (usually metarhitral, hyporhitral) in the Czech Republic.

Distribution in the Outer Western Carpathians of the Czech Republic and Slovakia: Moravskoslezské Beskydy Mts (Zelinka 1950, Hrabě et al. 1954, 1958, Straškraba \& Raušer 1954, Tuša 2001, Kroča 2002, 2013a) and Podbeskydská pahorkatina Upland (Straškraba \& Raušer 1954, Hrabě et al. 1958, Chovancová 1992, Kroča 2002, 2013b).

\section{Perla marginata (Panzer, 1799) (VU)}

Razula NNR, 19.iv.2003, 5 L; 24.v.2003, 8 L; 27.vii.2003, 2 L; 18.ix.2003, 5 L, all HS, 7.vi.2003, 1 § 3 ค , SW. A Western and Central European species occurring in similar habitats as Dinocras cephalotes. Distribution in the Outer Western Carpathians of the Czech Republic and Slovakia: Bílé Karpaty Mts (Krno 1994, Krno \& Horniak 2007); Moravskoslezské Beskydy Mts (Zelinka 1950, Hrabě et al. 1954, 1958, Straškraba \& Raušer 1954, Tuša 2001, Kroča 2002, 2013a) and Podbeskydská pahorkatina Upland (Straškraba \& Raušer 1954, Hrabě et al. 1958, Kroča 2002, 2013b).

\section{Diura bicaudata (Linnaeus, 1758)}

Razula NNR, 19.iv.2003, 1 L; 18.ix.2003, 12 L, both HS, 24.v.2003, 1 ㅇ, SW. Makyta, 16.viii.2006, 14 L; 30.x.2006, 4 L; 12.ii.2007, 1 L; 6.viii.2007, 11 L; 8.x.2007, 2 L; 10.iii.2008, 2 L, all HS. Malá Tisová, 16.viii.2006, 1 L; 6.viii.2007, 1 L; 8.x.2007, 1 L, all HS.

A Holarctic species; in Europe, occurs in Fennoscandia, Alps, Hercynian mountains and Carpathian mountains. In the Czech Republic, it inhabits small streams of montane and submontane zones.

Distribution in the Outer Western Carpathians of the Czech Republic and Slovakia: Bílé Karpaty Mts (Krno 1994, Krno \& Horniak 2007, Bojková et al. 2012) and Moravskoslezské Beskydy Mts (Hrabě et al. 1958, Tuša 2001, Kroča 2002, 2012, 2013a).

\section{Isoperla sudetica (Kolenati, 1860)}

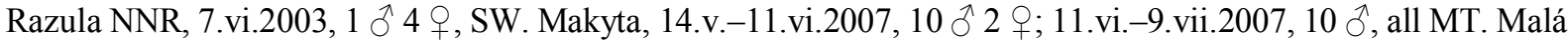
Tisová, 16.iv.-14.v.2007, 1 ô; 14.v.-11.vi.2007, 2 ô 3 क; 11.vi.-9.vii.2007, 5 ô 6 + , all MT.

A Central European species, common in the Czech Republic (including the Carpathian part). It occurs mainly in upper parts of the mountain streams (hypocrenal, epirhitral).

Distribution in the Outer Western Carpathians of the Czech Republic and Slovakia: Bílé Karpaty Mts (Krno 1994, Krno \& Horniak 2007, Bojková et al. 2012) and Moravskoslezské Beskydy Mts (Kroča 2012, 2013a).

\section{Siphonoperla neglecta (Rostock, 1888)}

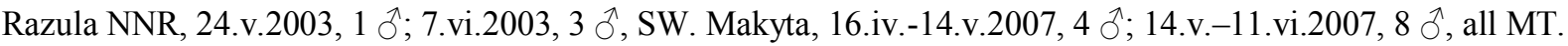
Malá Tisová, 14.v.-11.vi.2007, 4 ô, MT.

A Southern and Central European species occurring in small streams of mountains and submountain zones (hypocrenal, epirhitral).

Distribution in the Outer Western Carpathians of the Czech Republic and Slovakia: Bílé Karpaty Mts (Krno 1994, Krno \& Horniak 2007, Bojková et al. 2012); Moravskoslezské Beskydy Mts (Hrabě et al. 1954, Tuša 2001, Kroča 2002, 2012, 2013a) and very rare in the Podbeskydská pahorkatina Upland (Kroča 2013b). 


\section{Siphonoperla sp.}

Razula NNR, 24.v.2003, 2 \%; 7.vi.2003, 7 + , SW. Makyta, 16.iv.-14.v.2007, 1 क; 14.v.-11.vi.2007, 11 क; 11.vi.9.vii.2007, 2 ㅇ, all MT. Malá Tisová, 14.v.-11.vi.2007, 10 ㅇ, MT.

The identification of females of the genus is ambiguous. Occurrence of females Siphonoperla torrentium is possible.

\section{Brachyptera risi (Morton 1896)}

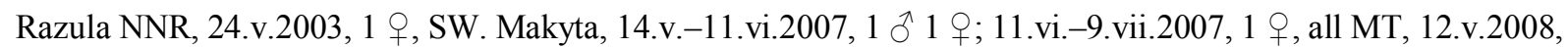

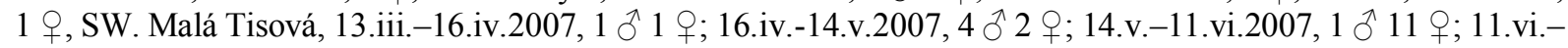
9.vii.2007, 2 + , all MT.

A European species generally common in the Czech Republic (including the Carpathian part), especially in submontane and colline habitats (Bojková et al. 2011). It occurs from hypocrenal to hyporhitral parts.

Distribution in the Outer Western Carpathians of the Czech Republic and Slovakia: Bílé Karpaty Mts (Krno \& Horniak 2007, Bojková et al. 2012); Moravskoslezské Beskydy Mts (Hrabě et al. 1954, Tuša 2001, Kroča 2012, 2013a) and Podbeskydská pahorkatina Upland (Kroča 2013b).

\section{Brachyptera seticornis (Klapalek 1902)}

Makyta, 14.v.-11.vi.2007, 1 +, MT. Malá Tisová, 14.v.-11.vi.2007, 2 + , MT.

A Central and Southern European species, the most common and abundant species of the family Taeniopterygidae in the Czech Republic (including the Carpathian part). It occurs from hypocrenal to metarhitral parts of montane and submontane streams (Bojková et al. 2011).

Distribution in the Outer Western Carpathians of the Czech Republic and Slovakia: Bílé Karpaty Mts (Krno \& Horniak 2007, Bojková et al. 2012); Moravskoslezské Beskydy Mts (Hrabě et al. 1954, 1958, Straškraba \& Raušer 1954, Tuša 2001, Kroča 2002, 2012, 2013a) and Podbeskydská pahorkatina Upland (Kroča 2013b).

\section{Protonemura aestiva Kis, 1965}

Makyta, 16.iv.-14.v.2007, 1 o ; 14.v.-11.vi.2007, 8 o; 11.vi.-9.vii.2007, 8 o; 9.vii.-6.viii.2007, 6 ô; 6.viii.5.ix.2007, 2 o, all MT. Malá Tisová, 14.v.-11.vi.2007, 2 ô; 11.vi.-9.vii.2007, 3 ó; 9.vii.-6.viii.2007, 3 o; 6.viii.5.ix.2007, 2 oै; 5.ix.-8.x.2007, 1 今ै, all MT.

A Balkan-Carpathian species which is common and abundant in the montane and submontane springs and brooks.

Distribution in the Outer Western Carpathians of the Czech Republic and Slovakia: Bílé Karpaty Mts (Bojková \& Špaček 2006, Bojková et al. 2012); Vizovická vrchovina Highland (Bojková et al. 2012) and Moravskoslezské Beskydy Mts (Bojková \& Špaček 2006, Kroča 2012, 2013a).

\section{Protonemura auberti Illies, 1954}

Makyta, 14.v.-11.vi.2007, 1 §ं; 11.vi.-9.vii.2007, 1 §, all MT.

A Central European species which is common in the Czech Republic (especially in Bohemia) and occurs in similar habitats as Protonemura aestiva.

Distribution in the Outer Western Carpathians of the Czech Republic and Slovakia: Bílé Karpaty Mts (Krno 1994, Krno \& Horniak 2007, Bojková et al. 2012) and Moravskoslezské Beskydy Mts (Hrabě et al. 1954, Raušer 1956, Tuša 2001, Kroča 2012, 2013a). 


\section{Protonemura spp.}

Makyta, 14.v.-11.vi.2007, 4 o ; 11.vi.-9.vii.2007, 7 ; 9.vii.-6.viii.2007, 10 o ; 6.viii.-5.ix.2007, 4 क; 5.ix.8.x.2007, 10 + , all MT. Malá Tisová, 11.vi.-9.vii.2007, 6 +; 9.vii.-6.viii.2007, 5 +; 6.viii.-5.ix.2007, 9 क; 5.ix.8.x.2007, 10 + ; 8.x.-4.xi.2007, 1 +, all MT.

The identification of females of species $P$. auberti and $P$. aestiva is ambiguous. The material cited above includes a mixture of females of this species.

\section{Protonemura praecox (Morton, 1894)}

Malá Tisová, 13.iii.-16.iv.2007, 1 § 1 \&, MT.

This species occurs in Southern, Central Europe and the British Isles. In the Czech Republic, it occurs in small streams (hypocrenal, epirhitral) of montane and submontane zones.

Distribution in the Outer Western Carpathians of the Czech Republic and Slovakia: Bílé Karpaty Mts (Krno 1994, Krno \& Horniak 2007, Bojková et al. 2012) and Moravskoslezské Beskydy Mts (Raušer 1956, Hrabě et al. 1954, 1958, Kroča 2013a).

\section{Nemoura cambrica Stephens, 1836}

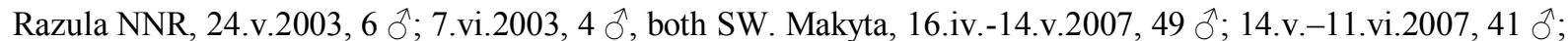

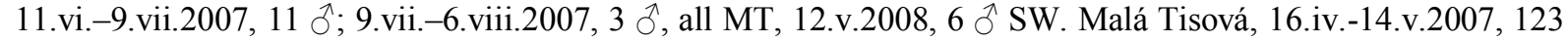

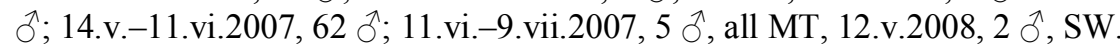

A European species common in running waters from montane to planar zones in the Czech Republic.

Distribution in the Outer Western Carpathians of the Czech Republic and Slovakia: Bílé Karpaty Mts (Krno 1994, Krno \& Horniak 2007, Bojková et al. 2012); Vizovická vrchovina Highland (Bojková et al. 2012); Moravskoslezské Beskydy Mts (Hrabě et al. 1954, Tuša 2001, Kroča 2002, 2012, 2013a) and Podbeskydská pahorkatina Upland (Kroča 2013b).

\section{Nemoura carpathica Illies, 1963}

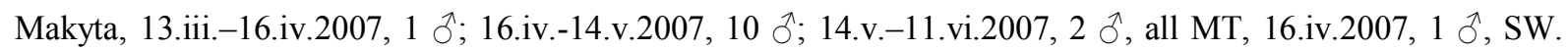
Malá Tisová, 16.iv.-14.v.2007, 1 ô, MT.

A Carpathian-Anatolian species which occurs from eucrenal to epirhitral sections of streams in the montane zone in the Czech Republic.

Distribution in the Outer Western Carpathians of the Czech Republic and Slovakia: Bílé Karpaty Mts (Bojková \& Špaček 2006, Bojková et al. 2012) and Moravskoslezské Beskydy Mts (Bojková \& Špaček 2006, Kroča 2012, 2013a).

\section{Nemoura cinerea (Retzius, 1783)}

Makyta, 9.vii.-6.viii.2007, 1 ${ }^{2}$, MT.

A Euro-Siberian species, generally very common and ubiquitous, inhabiting both running and standing waters.

Distribution in the Outer Western Carpathians of the Czech Republic and Slovakia: Bílé Karpaty Mts (Krno 1994, Krno \& Horniak 2007, Bojková et al. 2012); Vizovická vrchovina Highland (Bojková et al. 2012); Moravskoslezské Beskydy Mts (Hrabě et al. 1954, Straškraba \& Raušer 1954, Tuša 2001, Kroča 2012, 2013a) and Podbeskydská pahorkatina Upland (Kroča 2013b).

\section{Nemoura flexuosa Aubert, 1949}

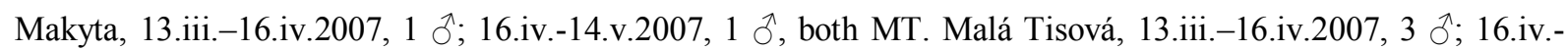
14.v.2007, 53 §ं; 14.v.-11.vi.2007, 5 §, all MT. 
A European-Anatolian species (missing in the British Isles and the Iberian Peninsula). In the Czech Republic, it is generally common in rhitral parts of submontane and montane streams.

Distribution in the Outer Western Carpathians of the Czech Republic and Slovakia: Bílé Karpaty Mts (Krno 1994, Krno \& Horniak 2007, Bojková et al. 2012); Moravskoslezské Beskydy Mts (Hrabě et al. 1954, Kroča 2013a) and Podbeskydská pahorkatina Upland (Kroča 2002, 2013b).

\section{Nemoura fusca Kis, 1963}

Makyta, 13.iii.-16.iv.2007, 3 §; 16.iv.-14.v.2007, 2 §; 14.v.-11.vi.2007, 1 §, all MT.

A Carpathians species, rare in the Czech Republic. It occurs in upper parts of montane brooks.

Distribution in the Outer Western Carpathians of the Czech Republic and Slovakia: Bílé Karpaty Mts (Bojková \& Špaček 2006, Bojková et al. 2012) and Moravskoslezské Beskydy Mts (Bojková \& Špaček 2006, Kroča 2012, 2013a).

\section{Nemoura marginata Pictet, 1835}

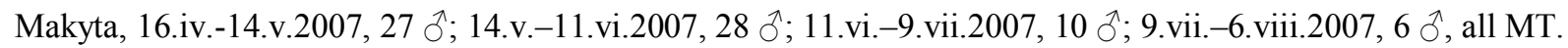

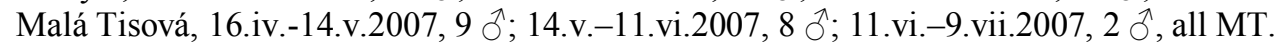

A Southern and Central European species occurring also in the Middle East. It is generally common species of small brooks (mainly eucrenal and hypocrenal) in montane and submontane zones in the Czech Republic.

Distribution in the Outer Western Carpathians of the Czech Republic and Slovakia: Bílé Karpaty Mts (Krno 1994, Krno \& Horniak 2007, Bojková et al. 2012); Vizovická vrchovina Highland (Bojková et al. 2012); Moravskoslezské Beskydy Mts (Zelinka 1950, Hrabě et al. 1954, Tuša 2001, Kroča 2012, 2013a) and Podbeskydská pahorkatina Upland (Kroča 2013b).

\section{Nemoura sciurus Aubert, 1949}

Makyta, 16.iv.-14.v.2007, 2 đ̊; 14.v.-11.vi.2007, 1 đ̂, all MT. Malá Tisová, 16.iv.-14.v.2007, 18 ô; 14.v.11.vi.2007, 11 ô, all MT.

A Central European species. In the Czech Republic, it is generally infrequent in Bohemia (Křelinová 1962, Bojková et al. 2010) and more common in the Carpathians (Moravia, Silesia). It occurs in upper parts of streams (from eucrenal to epirhitral) from colline to montane zone.

Distribution in the Outer Western Carpathians of the Czech Republic and Slovakia: Bílé Karpaty Mts; Vizovická vrchovina Highland (both Bojková et al. 2012); Moravskoslezské Beskydy Mts (Kroča 2012) and Podbeskydská pahorkatina Upland (Kroča 2013b).

\section{Nemoura sp.}

Razula NNR, 24.v.2003, 10 \% ; 7.vi.2003, 14 \%; 27.vii.2003, 1 + , all SW. Makyta, 13.iii.-16.iv.2007, 6 \%; 16.iv.14.v.2007, 126 क; 14.v.-11.vi.2007, 278 +; 11.vi.-9.vii.2007, 115 क; 9.vii.-6.viii.2007, 17 + , all MT, 12.v.2008, 16 +, SW. Malá Tisová, 13.iii.-16.iv.2007, 8 क; 16.iv.-14.v.2007, 194 +; 14.v.-11.vi.2007, 243 क; 11.vi.9.vii.2007, 37 क ; 9.vii.-6.viii.2007, 1 क; 6.viii.-5.ix.2007, 1 \%, all MT, 12.v.2008, 16 क, SW.

The above-mentioned material includes only females that could not be identified with certainty. The identification of females of the genus Nemoura is ambiguous.

\section{Nemurella pictetii Klapálek, 1900}

Makyta, 16.iv.-14.v.2007, 1 đ 3 + ; 14.v.-11.vi.2007, 3 đ 2 q, both MT. Malá Tisová, 13.iii.-16.iv.2007, 1 q;

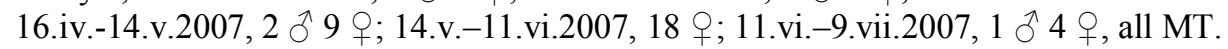

A Euro-Siberian species, common in the Czech Republic. It prefers eucrenal, but can occur up to epipotamal and in the littoral zone of stagnant waters from the planar to the alpine zones. 
Distribution in the Outer Western Carpathians of the Czech Republic and Slovakia: Bílé Karpaty Mts (Krno 1994, Bojková et al. 2012); Vizovická vrchovina Highland (Bojková et al. 2012); Moravskoslezské Beskydy Mts (Hrabě et al. 1958, Kroča 2012, 2013a) and Podbeskydská pahorkatina Upland (Kroča 2013b).

\section{Leuctra albida Kempny, 1899}

Malá Tisová, 11.vi.-9.vii.2007, 1 \&, MT.

Species known from Southern and Central Europe (except the Iberian and Apennine Peninsulas). In the Czech Republic, it is common and relatively abundant and prefers epirhitral and metarhitral parts of streams in montane and submontane zones.

Distribution in the Outer Western Carpathians of the Czech Republic and Slovakia: Bílé Karpaty Mts (Krno 1994, Krno \& Horniak 2007, Bojková et al. 2012); Moravskoslezské Beskydy Mts (Straškraba \& Raušer 1954, Hrabě et al. 1954, 1958, Tuša 2001, Kroča 2002, 2012, 2013a) and Podbeskydská pahorkatina Upland (Hrabě et al. 1958, Kroča 2013b).

\section{Leuctra armata Kempny, 1899}

Makyta, 14.v.-11.vi.2007, 1 + , MT.

Species occurring in the Alps and Carpathians (Graf et al. 2009). In the Czech Republic, it was recorded mainly from the Carpathians, but several records are known also from the Hercynian mountains (Soldán \& Helešic 1999, Stehno 2000). The species prefers eucrenal and hypocrenal parts of streams in montane and submontane zones.

Distribution in the Outer Western Carpathians of the Czech Republic and Slovakia: Bílé Karpaty Mts (Krno 1994) and Moravskoslezské Beskydy Mts (Straškraba \& Raušer 1954, Hrabě et al. 1958, Tuša 2001, Kroča 2002, 2012, 2013a).

\section{Leuctra braueri Kempny, 1898}

Published records. Kroča (2003): Razula NNR.

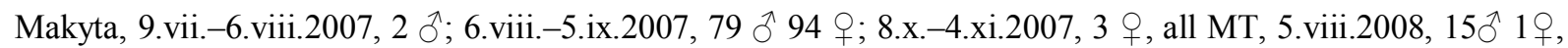

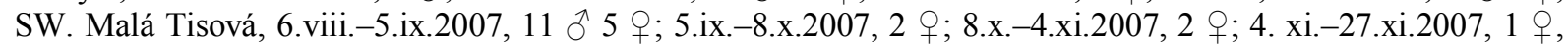
all MT.

A Central European species, widespread in small brooks and springs of montane and submontane zones in the Czech Republic.

Distribution in the Outer Western Carpathians of the Czech Republic and Slovakia: Bílé Karpaty Mts (Krno 1994, Krno \& Horniak 2007, Bojková et al. 2012); Vizovická vrchovina Highland (Bojková et al. 2012); Moravskoslezské Beskydy Mts (Hrabě et al. 1954, Tuša 2001, Kroča 2002, 2012, 2013a) and Podbeskydská pahorkatina Upland (Kroča 2013b) where is very rare.

\section{Leuctra digitata Kempny, 1899}

Malá Tisová, 5.ix.-8.x.2007, 1 +, MT.

A European species (missing in the British Isles and eastern European Lowlands). In the Czech Republic, it is widespread species inhabiting various brooks and streams, predominantly in submontane and colline zones.

Distribution in the Outer Western Carpathians of the Czech Republic and Slovakia: Bílé Karpaty Mts (Krno 1994, Krno \& Horniak 2007, Bojková et al. 2012); Vizovická vrchovina Highland (Bojková et al. 2012); Moravskoslezské Beskydy Mts (Kroča 2010a, 2012, 2013a) and Podbeskydská pahorkatina Upland (Kroča 2010a, 2013b). 


\section{Leuctra hippopus Kempny, 1899}

Razula NNR, 24.v.2003, 4 ㅇ, SW. Makyta, 13.iii.-16.iv.2007, 3 o 5 o ; 16.iv.-14.v.2007, 5 o 4 ㅇ, all MT,

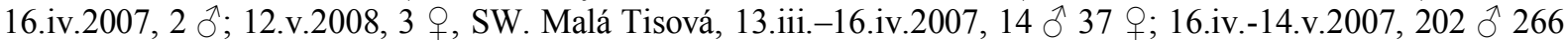
क; 14.v.-11.vi.2007, 7 § 21 क , all MT.

A western Palaearctic species, generally common in small brooks, streams and rivers in montane and submontane zones in the Czech Repubic.

Distribution in the Outer Western Carpathians of the Czech Republic and Slovakia: Bílé Karpaty Mts (Krno 1994, Krno \& Horniak 2007, Bojková et al. 2012); Moravskoslezské Beskydy Mts (Hrabě et al. 1954, 1958, Tuša 2001, Kroča 2002, 2012, 2013a) and Podbeskydská pahorkatina Upland (Kroča 2002, 2013b).

\section{Leuctra cf. major Brinck, $1949 \quad$ (EN)}

Razula NNR, 27.vii.2003, 1 L, HS.

A Central and Southern European species occurring mainly in epirhitral and hyporhitral parts of montane and submotane streams. Larva was originally misidentified as L. leptogaster in Kroča (2003), the specimen is morphologically identical with the material of $L$. major from the Moravskoslezské Beskydy Mts and Podbeskydská pahorkatina Upland. The occurrence of $L$. major is also indirectly supported by the findings of Dinocras cephalotes and Perla marginata which co-occured with L. major in Moravskoslezské Beskydy Mts (Kroča 2013a,b and unpublished data).

Distribution in the Carpathians of the Czech Republic: historically documented from the Bílé Karpaty Mts (Bojková et al. 2012), recently only in the Moravskoslezské Beskydy Mts (Kroča 2013a) and Podbeskydská pahorkatina Upland (Kroča 2002, 2013b).

\section{Leuctra nigra (Olivier, 1811)}

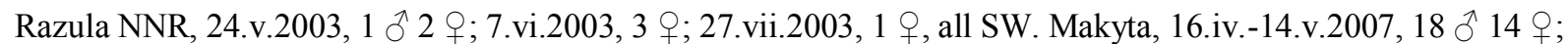

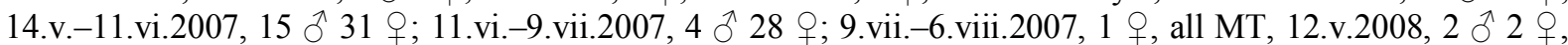

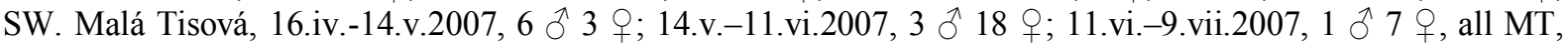
12.v.2008, 2 +, SW.

A European species (missing in the Iberian Peninsula and eastern European Lowlands). In the Czech Republic, it is very common and abundant species that prefers small forest brooks and springs and it can also inhabit slow-flowing, muddy brooks and acidic waters in all altitude zones.

Distribution in the Outer Western Carpathians of the Czech Republic and Slovakia: Bílé Karpaty Mts (Krno 1994, Krno \& Horniak 2007, Bojková et al. 2012); Vizovická vrchovina Highland (Bojková et al. 2012); Moravskoslezské Beskydy Mts (Straškraba \& Raušer 1954, Hrabě et al. 1954, 1958, Tuša 2001, Kroča 2012, 2013a) and Podbeskydská pahorkatina Upland (Kroča 2013b).

\section{Leuctra prima Kempny, 1899}

Makyta, 13.iii.-16.iv.2007, 28 o; 16.iv.-14.v.2007, 4 §, both MT. Malá Tisová, 13.iii.-16.iv.2007, 30 đ; 16.iv.14.v.2007, 20 §, both MT.

A European species (missing in Fennoscandia and the British Isles). In the Czech Republic, it is rare or medium distributed species preferring small streams (hypocrenal, epirhitral) of montane, submontane and colline zones.

Distribution in the Outer Western Carpathians of the Czech Republic and Slovakia: Bílé Karpaty Mts (Krno 1994, Krno \& Horniak 2007, Bojková et al. 2012); Vizovická vrchovina Highland (Bojková et al. 2012) and the Moravskoslezské Beskydy Mts (Zelinka 1950, Kroča 2012, 2013a). 


\section{Leuctra pseudosignifera Aubert, 1954}

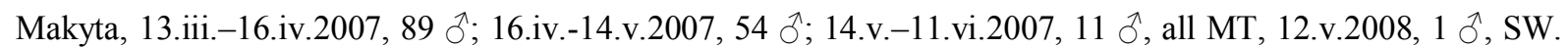
Malá Tisová, 13.iii.-16.iv.2007, 10 ○े; 16.iv.-14.v.2007, 19 §, both MT.

A Western-Central European species (missing in Fennoscandia and the British Isles) which inhabits mountain and submountain small streams (up to metarhitral).

Distribution in the Outer Western Carpathians of the Czech Republic and Slovakia: Bílé Karpaty Mts (Krno 1994, Krno \& Horniak 2007, Bojková et al. 2012), Moravskoslezské Beskydy Mts (Kroča 2012, 2013a) and the Podbeskydská pahorkatina Upland (Kroča 2013b) where is very rare.

\section{Leuctra spp. prima subgr.}

Razula NNR, 24.v.2003, 2 +, SW. Makyta, 13.iii.-16.iv.2007, 183 q; 16.iv.-14.v.2007, 182 q; 14.v.-11.vi.2007, 52 +; 11.vi.-9.vii.2007, 1 \%, all MT, 16.iv.2007, 4 +; 12.v.2008, 3 + , SW. Malá Tisová, 13.iii.-16.iv.2007, 410 +; 16.iv.-14.v.2007, 238 +; 14.v.-11.vi.2007, 28 +, all MT, 12.v.2008, 3 +, SW.

The above-mentioned material includes only females which could not be identified with certainty. The identification of females in the Leuctra hippopus group, prima subgroup is ambiguous.

Specimens from the site of Razula were originally misidentified as L. rosinae (Kroča 2003).

\section{Leuctra quadrimaculata Kis, 1963 (NT)}

Published records. Kroča (2011): Makyta; Malá Tisová.

A Balkan-Carpathian species, very rare in the Czech Republic. It inhabits montane and submontane streams (mostly rhitral).

Distribution in the Outer Western Carpathians of the Czech Republic and Slovakia: Bílé Karpaty Mts (Bojková \& Špaček 2006, Bojková et al. 2012), Javorníky Mts (Kroča 2011) and Moravskoslezské Beskydy Mts (Kroča 2011, 2012).

\section{Leuctra spp. inermis gr.}

Published records. Kroča (2003): Razula NNR.

Makyta, 9.vii.-6.viii.2007, 1 \%, MT. Malá Tisová, 11.vi.-9.vii.2007, 12 +, MT.

The above-mentioned material includes only larvae from the Razula and females which could not be identified with certainty. The identification of females in the Leuctra inermis group ambiguous with the exception of $L$. rauscheri.

\section{Discussion and conclusions}

Altogether 28 species (30\% of recent fauna of stoneflies the Czech Republic) from 10 genera and 6 families were recorded from the Javorníky Mts. According to the updated national Red List of stoneflies (Bojková \& Soldán 2013), one species is endangered (Leuctra cf. major), two species are vulnerable (Dinocras cephalotes, Perla marginata) and one species is near threatened (Leuctra quadrimaculata).

Revision of the material from Razula NNR resulted in more accurate determination (Kroča 2003). Altogether three species have been misidentified. Specimens previously determined as Isoperla grammatica belong to I. sudetica. Two females of L. rosinae was newly identified as $L$. spp. prima subgr. Specimen previously determined as Leuctra leptogaster is probably $L$. major.

When compared with the nearby Carpathian geomorphological units of the Bílé Karpaty Mts, Vizovická vrchovina Highland (39 species; Krno \& Horniak 2007, Bojková \& Špaček 2006, Bojková et al. 2012), and the Moravskoslezské Beskydy Mts, Podbeskydská pahorkatina 
Upland (62 species; Bojková \& Špaček 2006, Bojková \& Kroča 2011, Kroča 2002, 2010a,b,c, 2011, 2012, 2013a,b), the number of stonefly species recorded in the Javorníky Mts is rather low. It is due to a small number of sites and monitored habitats (only hypocrenal and epirhitral parts of streams in montane zone in the northern part of Javorníky Mts). Despite this fact, it can be assumed based on the spectrum of the species recorded that the species richness of stoneflies of the Javorníky Mts can be significantly higher.

On a geographic gradient from the Moravskoslezské Beskydy Mts (higher, colder and more rugged) to the Bílé Karpaty Mts (lower, warmer and more homogeneous), the Javorníky Mts are probably situated between two extreme positions and local occurrence of specific species from both areas can be assumed. The occurrence of Isoperla tripartita known from the Bílé Karpaty Mts, the Vizovická vrchovina Highland and Nemoura dubitans, Protonemura meyeri, Capnia vidua, Leuctra dalmoni, L. inermis, L. pusilla and L. rauscheri known from the Moravskoslezské Beskydy Mts is highly probable in the Javorníky Mts. From the species widespread in the Carpathian part of the Czech Republic, the occurrence of I. grammatica, I. oxylepis, Perlodes microcephalus, Perla abdominalis, Siphonoperla torrentium, Amphinemura standfussi, A. sulcicicollis, Protonemura intricata, Zwicknia bifrons, Leuctra autumnalis and L. fusca is highly probable.

The fauna of stoneflies of the Javorníky Mts can include more than 40 species and can form a continuous transition between two significantly different geomorphological units of the Outer Western Carpathians.

Acknowledgements: I express my gratitude to the management staff of the Beskydy PLA Administration for the support of my research. This study was supported by the Ministry of the Environment of the Czech Republic (MZP 0002071101). Thanks are due to Jana Ošlejšková for processing the map. I would like to thank Jindřrška Bojková for critical reading the manuscript and correcting the English.

\section{References}

Bojková J. (2009): Revision of the stonefly collections (Plecoptera) by E. Křelinová and J. Raušer from the Czech Republic. - Aquatic Insects 31(Suppl. 1): 249-255.

Bojková J. \& Kroča J. (2011): Historic and current distribution of an endangered stonefly Perla grandis (Plecoptera: Perlidae) in the Czech Republic. - Klapalekiana 47: 153-163.

Bojková J. \& Soldán T. (2013): Stoneflies (Plecoptera) of the Czech Republic: species checklist, distribution and protection status. - Acta Entomologica Musei Nationalis Prague 53 (2): 443-484.

Bojková J., Soldán T., Špaček J. \& Straka M. (2011): Distribution of stoneflies of the family Taeniopterygidae (Plecoptera) in the Czech Republic: earlier data, new records and recent distributional changes. - Čas. Slez. Muz. Opava (A) 60: 239-258.

Bojková J., Soldán T., Zahrádková S., Chvojka P. \& Trýzna M. (2010): Ephemeroptera and Plecoptera of the Bohemian Switzerland National Park, Czech Republic: species diversity and taxocenoses of sandstone watercourses. - Lauterbornia 70: 91-110.

Bojková J., Chvojka P. \& Komzák P. (2012): Stoneflies (Plecoptera) of the Bílé Karpaty Protected Landscape Area and Biosphere Reserve (Czech Republic) In: Malen ov ský I., Kment P. \& Kon vička O. (eds): Species inventories of selected insect groups in the Bílé Karpaty Protected Landscape Area and Biosphere Reserve (Czech Republic). - Acta Musei Moraviae, Scientiae Biologicae 96(2) (2011): 37-70.

Bojková J. \& Špaček J. (2006): New and interesting records of Plecoptera (Insecta) from the Czech Republic. - Acta Musei Moraviae, Scientiae Biologicae 91: 1-6.

Demek J. \& Mackovčin P. (eds) (2006): Hory a nížiny. Zeměpisný lexikon ČR. Agentura ochrany př́rody a krajiny ČR, Brno, 582 pp.

Hrabě S., Obr S., Kubíček F., Raušer J., Zelinka M. \& Marvan P. (1954): Zpráva o výsledcích hydrobiologických šetření v povodí budoucí přehrady u Šanců. Zoologický ústav Př́rodovědecké fakulta university v Brně a Výzkumný ústav vodohospodářský Praha, laboratoře v Brně, ms., 37 pp.

Hrabě S., Kubíček F., Obr S., Raušer J., Zelinka M. \& Knoz J. (1958): Výsledky hydrobiologických šetření v povodí budoucí údolní nádrže na Morávce. Zoologický ústav Př́rodovědecké fakulta university v Brně, ms., $29 \mathrm{pp}$. 
Chovancová I. (1992): Předběžný inventarizační průzkum makrozoobentosu v CHPV Profil Morávky. Závěrečná zpráva, depon in.: Muzeum Beskyd Frýdek - Místek, ms., 11 pp.

Kis B. (1974): Plecoptera, Insecta. Fauna Rep. Soc. Romania. Vol. 8. Acad. Rep. Soc. Romania, Bucuresti, 273 pp.

Kokeš J. \& Němejcová D. (2006): Metodika odběru a zpracování vzorku makrozoobentosu tekoucích vod metodou PERLA. VÚV T.G.M. Praha, 10 pp.

Krno I. (1994): Pošvatky Bielych Karpát. - Acta Musealia Muzea Jihovýchodní Moravy ve Zlíně, řada B 5: 511.

Krno I. \& Horniak P. (2007): Pošvatky (Plecoptera) slovenskej časti Bielych Karpát. - Acta Musealia Muzea Jihovýchodní Moravy ve Zlíně 7: 19-24.

Kroča J. (2002): Hydrobiologický průzkum řeky Morávky se zaměřením na makrozoobentos. Univerzita Palackého v Olomouci, Přírodovědecká fakulta, Katedra ekologie a životního prostředí, ms., 103 pp.

- (2003): Závěrečná zpráva k inventarizačnímu průzkumu NPR Razula část makrozoobentos. Ms., depon. in: Správa CHKO Beskydy, Rožnov pod Radhoštěm, 5 pp.

- (2010a): Leuctra digitata Kempny, 1899 (Plecoptera: Leuctridae) in the Moravskoslezské Beskydy Mts and Podbeskydská pahorkatina Upland region of the Czech Republic. - Čas. Slez. Muz. Opava (A) 59: 71-75.

- (2010b): Arcynopteryx compacta (Mac Lachlan, 1872) and Isogenus nubecula Newman, 1833 (Plecoptera, Perlodidae) in the Moravskoslezské Beskydy Mts (Czech Republic). - Čas. Slez. Muz. Opava (A) 59: 159164.

- (2010c): The first record of Leuctra bronislawi (Plecoptera, Leuctridae) in the Czech Republic. - Čas. Slez. Muz. Opava (A) 59: 198-202.

- (2011): Leuctra quadrimaculata Kis, 1963 (Plecoptera; Leuctridae) in the Moravskoslezské Beskydy Mts and Javorníky Mts (Czech Republic). - Čas. Slez. Muz. Opava (A) 60: 57-62.

- (2012): Inventarizační průzkum NPR Salajka z oboru hydrobiologie. Závěrečná zpráva, ms., depon. in: Správa CHKO Beskydy, Rožnov pod Radhoštěm; Výzkumný Ústav Vodohospodářský T.G.M., v.v.i., pobočka Brno, $28 \mathrm{pp}$.

- (2013a): Inventarizační průzkum NPR Kněhyně - Čertův mlýn z oboru hydrobiologie. Závěrečná zpráva, ms., depon. in: Správa CHKO Beskydy, Rožnov pod Radhoštěm; Výzkumný Ústav Vodohospodářský T.G.M., v.v.i., pobočka Brno, 32 pp.

- (2013b): Inventarizační průzkum NPP Skalická Morávka z oboru hydrobiologie. Závěrečná zpráva, ms., depon. in: Správa CHKO Beskydy, Rožnov pod Radhoštěm; Výzkumný Ústav Vodohospodářský T.G.M., v.v.i., pobočka Brno, 104 pp.

Křelín ová E. (1962): K poznání českých pošvatek (Plecoptera). Studie o bionomii a zoogeografi i bentické české zvířeny. Ms., Institute of Entomology, Prague, 265 pp.

Pruner L. \& Míka P. (1996): Seznam obcí a jejich částí v České republice s čísly mapových polí pro sít’ové mapování fauny. - Klapalekiana 32 (Suppl.): 1-175.

Raušer J. (1956): K poznání československých larev rodu Protonemura. - Práce Brněnské Základny Československé Akademie Věd 27: 449-498.

- (1980): К̌ád Pošvatky - Plecoptera. Pp. 86-132. In: Rozkošný R. (ed.): Klíč k určování vodních larev hmyzu, Academia, Praha, 521 pp.

Soldán T. \& Helešic J. (1999): Faunistic Records from the Czech Republic - 80. Plecoptera: Leuctridae. Klapalekiana 35: 24.

Soldán T., Zahrádková S., Helešic J., Dušek L. \& Landa V. (1998): Distributional and quantitative patterns of Ephemeroptera and Plecoptera in the Czech Republic: A possibility of detection of long-term changes of aquatic biotopes. - Folia Facultatis Scientiarum Naturalium Universitatis Masarykianae Brunensis, Biologia 98: 1-305.

Stehno V. (2000): Vliv úprav potoka Staviště (CHKO Žd'árské vrchy) na zoobentos. (Impact of regulation of the Staviště brook on zoobenthos (Žd'árské vrchy PLA, Bohemia, Czech Republic). - Bulletin Lampetra 4: 87104.

Straškraba M. \& Raušer J. (1954): Plecoptera. Pp. 260-268. In: Straškraba M. (ed.): Sborník o fauně a flóře řek Lučiny a Morávky se zvláštním zřetelem ke stavbě přehrad na těchto řekách. Ms., depon in: Slezské zemské muzeum, Opava. Biologická fakulta Karlovy university v Praze, 559 pp.

Tuša I. (2001): K výskytu pošvatek (Plecoptera) na severní Moravě v letech 1975-2000. Ms., závěrečná zpráva, depon in: Slezské zemské muzeum, Opava, 22 pp.

Vinçon G. \& Muranyi D. (2007): Leuctra dalmoni, a new orophilic species with wide distribution in Europe (Plecoptera). - Nouvelle Revue d'Entomologie (N.S.) 23: 237-248.

Zelený J. (1972): Entwurf einer Gliederung der Tschechoslowakei für Zwecke der faunistischen Forschung (mit 5 Abb.). - Zprávy Československé Společnosti Entomologické při ČSAV 8: 3-16. 
Zelinka M. (1950): K poznání zviřreny horských potoků Slezských Beskyd. - Zvláštní Příloha Př́rodovědeckého Sborníku Ostravského Kraje 11: 3-28.

Author's address: Jiří Kroča, Výzkumný ústav vodohospodářský T. G. Masaryka v.v.i., Mojmírovo nám. 16, CZ - 61200 Brno, Czech Republic.

E-mail: jiri_kroca@vuv.cz 